\title{
Produksi dalam Islam
}

\author{
Mahfuz, S.Sos.I, M.E, M.Si
}

Dosen tetap Prodi Perbankan Syariah FAI Universitas Islam As-Syafi'iyah Email : mahfuznur.fai@uia.ac.id / apoet_ren@yahoo.com

\begin{abstract}
ABSTRAK
Manusia sebagai khalifah dimuka bumi, penciptaan manusia adalah penciptaan yang sempurna. Selain manusia diberikan akal dan daya, Allah memberikan fasilitas yang dibutuhkan manusia dan semuanya berada di bumi yang diciptakannya. Tujuan manusia dalam memakmurkan bumi adalah agar manusia dapat memenuhi apa yang dibutuhkan dan diinginkannnya selama di bumi, oleh karenanya manusia wajib bekerja dan berusaha.

Produksi adalah kegiatan awal dalam aktivitas ekonomi, produksi pada dasarnya bertujuan untuk menghasilkan barang dan jasa atau menghasilkan dan menambah nilai guna barang dan jasa. Produksi bukan hanya sebagai aktivitas dalam memenuhi kebutuhan pribadi tapi juga untuk mendapatkan keuntungan.

Produksi tidak hanya bertujuan menciptakan yang tidak ada menjadi ada, melainkan juga menghasilkan kegiatan produksi yang berdaya guna. Produksi dilandasi nilai-nilai islam dengan prinsip maqasid al-syari'ah. Produksi tidak bisa lepas dari faktor sebagai alat produksi berupa faktor alam/tanah, faktor tenaga kerja, faktor modal dan faktor manajemen/organisasi
\end{abstract}

Kata Kunci : Khalifah, produksi, tujuan produksi faktor produksi, fungsi produksi

\section{A. Pendahuluan}

Produksi adalah aktivitas menciptakan manfaat di masa kini dan mendatang, produksi juga merupakan proses transformasi input menjadi output, sehingga segala jenis input yang masuk ke dalam proses produksi untuk menghasilkan output disebut juga faktor produksi ${ }^{1}$. Islam menggambarkan kegiatan produksi sebagai sesuatu yang sangatlah indah, banyak dari ayat-ayat suci Al Quran yang menjelaskan mengenai pentingnya kegiatan produksi dan Allah SWT menyediakan fasilitas yang luar biasa banyaknya.

\footnotetext{
${ }^{1}$ Mustafa Edwin Nasution, et all, Pengenalan Eksklusif Ekonomi Islam, Kencana Prenada Media Grup, Jakarta, 2006. Hal 108
} 
Beberapa ahli ekonomi Islam memberikan definisi yang berbeda mengenai pengertian produksi, meskipun substansinya adalah sama. Berikut adalah beberapa pengertian produksi menurut para ekonom muslim kontemporer. ${ }^{2}$

a. Kahf (1992), kegiatan produksi dalam perspektif Islam sebagai usaha manusia untuk memperbaiki tidak hanya kondisi fisik materialnya, tetapi juga moralitas, sebagai sarana untuk mencapai tujuan hidup sebagaimana digariskan dalam Islam, yaitu kebahagiaan dunia dan akhirat.

b. Mannan (1992), menekankan pentingnya motif altruism (altruism) bagi produsen Islami sehingga ia menyikapi dengan hati-hati konsep pareto optimality dan given demand hypothesis yang banyak dijadikan sebagai konsep dasar produksi dalam ekonomi konvensional.

c. Rahman (1995), menekankan pentingnya keadilan dan kemerataan produksi (distribusi produksi secara merata).

d. Al Haq (1996), bahwa tujuan dari produksi adalah memenuhi kebutuhan barang dan jasa yang merupakan fardhu kifayah, yaitu kebutuhan yang bagi banyak orang pemenuhannya bersifat wajib.

e. Siddiqi (1992), kegiatan produksi sebagai penyediaan barang dan jasa dengan memperhatikan nilai keadilan dan kebajikan/ kemanfaatan (mashlahah) bagi masyarakat. Dalam pandangannya, sepanjang produsen telah bertindak adil dan membawa kebajikan bagi masyarakat maka ia telah bertindak islami.

Menurut M.A. Mannan, perilaku produksi tidak hanya menyandarkan pada kondisi permintaan pasar, melainkan juga berdasarkan pertimbangan kemaslahatan. Pendapat ini didukung oleh M.M. Metwally yang menyatakan bahwa fungsi kepuasan tidak hanya dipengaruhi oleh variabel tingkat keuntungan, tapi juga oleh veriabel pengeluaran yang bersifat charity dan good deeds, sehingga fungsi utilitas pengusaha muslim adalah ${ }^{3}: \mathrm{U}_{\max }=\mathrm{U}(\mathrm{F}, \mathrm{G})$ dimana $\mathrm{F}$ adalah tingkat keuntungan dan $\mathrm{G}$ adalah tingkat pengeluaran untuk good deeds/charity.

2 Pusat Pengkajian dan Pengembangan Ekonomi Islam (P3EI) Universitas Islam Indonesia Yogyakarta atas kerjasama dengan Bank Indonesia, PT Raja Grafindo Persada, 2008 hal 230

${ }^{3}$ Mustafa Edwin Nasution, et all, Pengenalan Eksklusif Ekonomi Islam, Kencana Prenada Media Grup, Jakarta, 2006. Hal 112 
Menurut Metwally pengeluaran perusahaan untuk good deeds/charity akan meningkatkan permintaan terhadap produk perusahaan, karena $G$ akan menghasilkan efek angka pengganda (multiplier effect) terhadap kenaikan kemampuan beli masyarakat. Kenaikan tersebut pada gilirannya akan meningkatkan permintaan terhadap produk perusahaan ${ }^{4}$.

\section{B. Tujuan, Prinsip, dan Kaidah Produksi dalam Islam}

\section{Tujuan Produksi dalam Islam}

Dalam Islam memproduksi sesuatu bukanlah sekadar untuk dikonsumsi sendiri atau dijual ke pasar. Dua motivasi tersebut belumlah cukup, Islam pada prinsipnya menekankan kegiatan produksi yang tidak hanya berhenti pada fungsi ekonominya saja tetapi juga harus bisa sejalan dengan fungsi sosial, sehingga untuk mencapai fungsi sosial kegiatan produksi harus mencapai surplus. ${ }^{5}$ Hal ini sesuai dengan kutipan surat Al Hadid 57:7

Berimanlah kamu kepada Allah dan Rasul-Nya dan nafkahkanlah sebagian dari hartamu yang Allah telah menjadikan kamu menguasainya ${ }^{6}$. Maka orang-orang yang beriman di antara kamu dan menafkahkan (sebagian) dari hartanya memperoleh pahala yang besar.

Melalui konsep tersebut, kegiatan produksi harus bergerak di atas dua garis optimalisasi. Tingkat optimal pertama adalah mengupayakan berfungsinya sumber daya insani ke arah pencapaian kondisi full employment, dimana semua orang bekerja dan menghasilkan suatu karya kecuali mereka yang udzur syar'i seperti sakit dan lumpuh. Optimalisasi yang kedua adalah memproduksi kebutuhan primer (dharuriyyat), sekunder (hajiyyat) dan tersier (tahsiniyyat) secara proporsional, sehingga tidak saja harus halal tetapi juga harus baik dan bermanfaat (thayyib). ${ }^{7}$

Berbeda dengan ekonomi konvensional yang mengedepankan memaksimalkan kuntungan dan kepuasan (maximization profit and utility), tujuan

\footnotetext{
${ }^{4}$ Ibid

${ }^{5}$ Mustafa Edwin Naution, et all, Pengenalan Eksklusif Ekonomi Islam, Kencana Prenada Media Grup, Jakarta, 2006. Hal 106

${ }^{6}$ Yang dimaksud dengan menguasai di sini ialah penguasaan yang bukan secara mutlak. hak milik pada hakikatnya adalah pada Allah. manusia menafkahkan hartanya itu haruslah menurut hukumhukum yang telah disyariatkan Allah. karena itu tidaklah boleh kikir dan boros.

7 Mustafa Edwin Naution, et all, Pengenalan Eksklusif Ekonomi Islam, Kencana Prenada Media Grup, Jakarta, 2006., hal 107
} 
yang ingin dicapai oleh kegiatan produksi dalam perspektif Islam adalah kecukupan setiap individu, swasembada ekonomi umat dan kontribusi untuk mencukupi kebutuhan umat dan bangsa lain. ${ }^{8}$

Pendapat lain yang mejelaskan mengenai tujuan produksi dalam perspektif Islam adalah menyediakan barang dan jasa yang memberikan mashlahah maksimum bagi konsumen. Secara lebih spesifik, tujuan kegiatan produksi adalah meningkatkan kemashlahatan yang bisa diwujudkan dalam berbagai bentuk, diantaranya adalah ${ }^{9}$ :

a. Pemenuhan kebutuhan manusia pada tingkatan moderat

b. Menemukan kebutuhan masyarakat dan pemenuhannya

c. Menyiapkan persediaan barang dan jasa di masa depan

d. Pemenuhan sarana bagi kegiatan social dan ibadah kepada Allah.

\section{Prinsip Produksi dalam Islam}

Prinsip produksi pada sistem konvensional adalah bagaimana produksi dapat berjalan sehingga mampu mencapai tingkat yang paling maksimum dan efisiensi dengan ${ }^{10}$ :

a. Memaksimalkan output dengan menggunakan input tetap

b. Meminimalkan penggunaan input untuk mencapai tingkat output yang sama

Prinsip-prinsip produksi pada perspektif ekonomi Islam tidak jauh berbeda dengan sistem konvensional yang membedakannya adalah nilai (value) yang terkandung di dalamnya. Islam menambahkan beberapa poin nilai berdasarkan AlQur'an dan Hadist Rasulullah SAW dimana Islam memberikan arahan mengenai prinsip-prinsip produksi sebagai berikut, yaitu ${ }^{11}$ :

a. Tugas manusia di bumi adalah sebagi khalifah Allah SWT yakni manusia ditugasi untuk memakmurkan bumi dengan ilmu dan amalnya.

\footnotetext{
${ }^{8}$ Ibid, hal 107

9 Pusat Pengkajian dan Pengembangan Ekonomi Islam (P3EI) Universitas Islam Indonesia Yogyakarta atas kerjasama dengan Bank Indonesia, PT Raja Grafindo Persada, 2008 hal 233

${ }^{10}$ Karim, Adiwarman. A, Ekonomi Mikro Islam, PT. Raja Grafindo Persada, Jakarta, 2007, hal 103

${ }_{11}$ Mustafa Edwin Naution, et all, Pengenalan Eksklusif Ekonomi Islam, Kencana Prenada Media Grup, Jakarta, 2006. hal 110-111
} 
b. Islam selalu mendorong kemajuan di bidang produksi, menurut Yusuf Qordhawi, Islam membuka lebar penggunaan metode ilmiah yang didasarkan atas penelitian, eksperimen, dan perhitungan. Akan tetapi Islam tidak membenarkan penuhanan terhadap hasil karya ilmu pengetahuan dalam arti melepaskan diri dari Al-Qur'an dan Al hadist.

c. Teknik produksi diserahkan kepada keinginan dan kemampuan manusia, sesuai dengan sabda Nabi yaitu: "kalian lebih mengatahui urusan dunia kalian"

d. Dalam berinovasi dan bereksperimen, pada prinsipnya agama Islam menyukai kemudahan, menghindari kemudharatan dan memaksimalkan manfaat. Dalam Islam tidak terdapat ajaran yang memerintahkan membiarkan segala urusan berjalan dalam kesulitannya, karena berdalih dengan ketetapan dan ketentuan Allah, atau karena tawakal kepada-Nya, sebagaimana keyakinan yang terdapat di dalam agama-agama selain Islam. Tawakal dan sabar adalah konsep penyerahan hasil kepada Allah SWT, sebagai pemilik hak prerogative yang menentukan segala sesuatu setelah segala usaha dan persyaratan dipenuhi dengan optimal.

\section{Kaidah Berproduksi dalam Islam}

Islam menuntun manusia sebagai khalifah Allah untuk memakmurkan bumi yang Allah ciptakan untuk dikelola dengan ilmu dan amalan baik. Melalui tuntunan kaidah tersebutlah manusia dituntut untuk melakukan sesuatu berdasarkan Al Quran dan Al Hadist, salah satunya adalah kaidah dalam berproduksi. Kaidahkaidah dalam berproduksi antara lain adalah ${ }^{12}$ :

a. Memproduksi barang dan jasa yang halal pada setiap tahapan produksi

b. Mencegah kerusakan di muka bumi, termasuk membatasi polusi, memelihara keserasian, dan ketersediaan sumber daya alam

c. Produksi dimaksudkan untuk memenuhi kebutuhan individu dan masyarakat serta mencapai kemakmuran. Kebutuhan yang harus dipenuhi harus berdasarkan prioritas yang ditetapkan agama, yakni terkait dengan kebutuhan

\footnotetext{
12 Mustafa Edwin Naution, et all, Pengenalan Eksklusif Ekonomi Islam, Kencana Prenada Media Grup, Jakarta, 2006. hal 111-112
} 
untuk tegaknya akidah/ agama, terpeliharanya nyawa, akal dan keturunan, serta memakmurkan material.

d. Produksi dalam Islam tidak dapat dipisahkan dari tujuan kemandirian umat. Untuk itu hendaknya umat memiliki berbagai kemampuan, keahlian, dan prasarana yang memungkinkan terpenuhinya kebutuhan pengembangan peradaban, dimana dalam kaitannya tersebut para ahli fiqih memandang bahwa pengembangan di bidang ilmu, industri, perdagangan, keuangan merupakan fardhu kifayah, yang dengannya manusia bias melaksanakan urusan agama dan dunianya.

e. Meningkatkan kualitas sumber daya manusia baik kualitas spiritual maupun mental dan fisik. Kualitas spiritual terkait dengan kesadaran rohaniahnya, kualitas mental terkait dengan etos kerja, intelektual, kreatifitas, sedangkan fisik berkaitan dengan kesehatan, efisiensi, dan sebagainya.

\section{Faktor-Faktor Produksi dalam Pandangan Islam}

Produksi yang baik dan berhasil adalah produksi yang menggunakan faktorfaktor produksi guna menghasilkan barang sebanyak-banyaknya dengan kualitas semanfaat mungkin. Menurut M.A. Mannan dan Afzalurrahman faktor produksi terdiri atas alam, tenaga kerja, modal dan manajemen (organisasi).

\section{Alam (Tanah)}

Ekonom klasik menganggap tanah sebagai suatu faktor produksi penting mencakup semua sumber daya alam yang digunakan dalam proses produksi ${ }^{13}$. Menurut Afzalurrahman, tanah termasuk segala sesuatu yang terdapat di permukaan bumi, seperti gunung, hutan; di bawah permukaan bumi dalam bentu bahan galian/tambang dan kekayaan laut; dan di atas permuakaan bumi, seperti hujan, angin, keadaan iklim, geografi, dan sebagainya ${ }^{14}$. Selanjutnya afzalurrahman menjelaskan bahwa tidak diragukan lagi faktor produksi yang paling penting adalah

\footnotetext{
${ }^{13}$ M.A. Mannan, Teori dan Praktek Ekonomi Islam, Yogyakarta: PT Dana Bhakti Prima Yasa, 1997, hal 55

${ }^{14}$ Afzalurrahman. Doktrin Ekonomi Islam Jilid 1. Terjemahan Soeroyo, Nastangin. Yogyakarta: PT Dana Bhakti Prima Yasa. 1995. hal 241
} 
permukaan tanah yang di atasnya kita dapat berjalan, mendirikan rumah, perusahaan, serta melakukan apa saja menurut kehendak kita ${ }^{15}$.

M.A. Mannan menjelaskan bahwa Islam tidak menyetujui definisi ilmu ekonomi modern, Islam mengakui tanah sebagai faktor produksi yang diciptakannya manfaat yang dapat memaksimalkan kesejahteraan ekonomi rakyat. Dimana kesejahteraan itu memperhatikan prinsip-prinsip dasar etika ekonomi.

Al-Qur'an dan sunnah banyak menekankan pembudidayaan tanah secara baik, antara lain adalah tentang perlunya mengubah tanah kosong menjadi kebunkebun dengan mengadakan pengaturan, pengairan, dan menanaminya dengan tanaman yang baik ${ }^{16}$. Dengan demikian tanah kosong diperkenankan untuk digarap orang lain bahkan dianjurkan orang yang mampu sebaiknya meminjamkan tanahnya tanpa sewa kepada orang yang miskin. Jadi Islam mengakui pemilikan tanah, bukan penggarapnya ${ }^{17}$

Jika tanah yang mengandung hara yang dibutuhkan tanaman, maka tanah tersebut dapat ditanami tumbuhan secara subur. Ketersedian air juga dapat menjaga kesuburan tanah. Islam sangat mementingkan pengairan guna meningkatkan produksi pertanian ${ }^{18}$. Dalam Islam, seseorang yang tanahnya dekat dengan saluran air maka ia berhak mengairi ladangnya. Namun ia juga harus membiarkan air itu mengalir ke lading-ladang lainnya bila kebutuhannya telah terpenuhi ${ }^{19}$.

Tanah sebagai salah satu faktor produksi dalam Islam dipergunakan dan dikembangkan (dikelola) guna menambah produksi. Namun Islam juga memberi batasan kepemilikan selama maksimal tiga tahun tanpa pemanfaatan tanah. Penggunaan tanah untuk aktifitas produksi ini dengan syarat hak miliknya merupakan tugas sosial dan khilafat dari Allah atas milik-Nya dalam penggunaannya.

Menurut Thahir Abdul Muhsin Sulaiman, dalam pemanfaatan alam perlu disadari bahwasanya tanah memiliki dua karakteristik, yaitu ${ }^{20}$ :

\footnotetext{
${ }^{15}$ Ibid. hal 226

${ }^{16}$ M.A. Mannan. Ibid. hal 56

${ }^{17}$ Siapa saja yang menanami tanah yang tiada pemiliknya akan lebih berhak atasnya (HR Bukhari)

${ }^{18}$ Muhammad, Ekonomi Mikro dalam Perspektif Islam. 2004. Yogyakarta: BPFE Yogyakarta. hal 223

${ }^{19}$ Kelebihan air janganlah ditahan sendiri, karena itu berarti menahan pertumbuhan tanaman (HR. Bukhari)

${ }^{20}$ Muhammad, Ekonomi Mikro dalam Perspektif Islam. 2004. Yogyakarta: BPFE Yogyakarta. hal 224
} 
a. Tanah sebagai sumber daya alam, dan

b. Tanah sebagai sumber daya alam yang dapat habis

dalam Islam, generasi kini dan masa yang akan datang memilki hak yang sama tas sumber daya alam. Maka dari itu, janganlah menyalahgunakan pemanfaatan sumber daya alam agar tidak menimbulkan bahaya bagi generasi mendatang.

Berdasarkan hal tersebut di atas, M.A. Mannan melontarkan kebijakan pedoman dalam mengelola tanah sebagai sumber daya, yaitu ${ }^{21}$ :

a. Pembangunan pertanian pada Negara muslim dapat ditingkatkan melalui metode penanaman intensif dan ekstensif jika dilengkapi dengan suatu pendidikan moral berdasarkan ajaran Islam

b. Pengahasilan yang diperoleh dari penggunaan sumber daya yang dapat habis harus lebih digunakan untuk pembangunan lembaga-lembaga sosial (seperti universitas, rumah sakit) dan untuk infrastrutur fisik daripada konsumsi sekarang ini.

c. Sewa ekonomis murni tidak boleh lebih digunakan untuk memenuhi tingkat pengeluaran konsumsi sekarang ini

\section{Tenaga Kerja}

Faktor tenaga kerja dalam aktivitas produksi merupakan upaya yang dilakukan manusia, baik berupa kerja pikiran maupun berupa kerja jasmani atau kerja pikir sekaligus jasmani dalam rangka menghasilkan barang dan jasa ekonomi yang dibutuhkan masyarakat. Menurut Afzalurrahman, tenaga kerja adalah segala usaha dan ikhtiar yang dilakukan oleh anggota badan atau pikiran untuk mendapat imbalan yang pantas. Termasuk semua jenis kerja yang dilakukan fisik maupun pikiran $^{22}$. Selanjutnya Afzalurrahman menjelaskan tenaga kerja sebagai salah satu faktor produksi mempunyai arti yang besar, karena semua kekayaan alam tidak berguna bila tidak dieksploitasi oleh manusia dan diolah oleh buruh.

\footnotetext{
${ }^{21}$ M.A. Mannan, Teori dan Praktek Ekonomi Islam, Yogyakarta: PT Dana Bhakti Prima Yasa, 1997, hal 58

${ }^{22}$ Afzalurrahman. Doktrin Ekonomi Islam Jilid 1. Terjemahan Soeroyo, Nastangin. Yogyakarta: PT Dana Bhakti Prima Yasa. 1995. hal 248
} 
Adam Smith mengatakan bahwa tenaga kerja adalah satu-satunya faktor produksi. Secara umum para ahli ekonomi berpendapat kerja adalah produsen satusatunya dan tenaga kerjalah pangkal produktifitas dari semua faktor produksi. Alam tidak bisa menghasilkan apa-apa tanpa tenaga kerja ${ }^{23}$.

Islam mengangkat nilai tenaga kerja dan menyuruh orang bekerja untuk mencapai penghidupan yang layak dan menghasilkan barang dan jasa yang menjadi kebutuhan manusia, maupun amal yang bersifat ibadah semata-mata karena Allah ${ }^{24}$. Tenaga kerja dalam Islam, tidak pernah terpisahkan dari kehidupan moral dan sosial, karena kode dan tingkah laku pekerja dan majikan berakar pada syariat. Mereka yang mempekerjakan buruh mempunyai tanggung jawab moral dan sosial. Tenaga kerja tidak diperbolehkan melakukan pekerjaan yang tidak diinginkan syari'at. Pekerja dan majikan juga tidak boleh saling memeras.

Menurut M.A. Mannan, dalam Islam buruh digunakan dalam arti yang lebih luas namun lebih terbatas. Lebih luas karena hanya memandang pada penggunaan jasa buruh di luar batas-batas pertimbangan keuangan. Terbatas dalam arti bahwa seorang pekerja tidak secara mutlak bebas untuk berbuat apa saja yang dikehendakinya dengan tenaga kerjanya itu ${ }^{25}$.

\section{Modal}

Menurut Ahmad Ibrahim, modal adalah kekayaan yang memberikan penghasilan kepada pemiliknya, atau kekayaan yang menghasilkan suatu hasil yang akan digunakan untuk menghasilkan suatu kekayaan lainnya ${ }^{26}$. Afzalurrahman menyatakan bahwa modal merupakan hasil kerja apabila pendapatan melebihi pengeluaran, sehingga faktor utama pengumpulan modal adalah peningkatan pendapatan $^{27}$. Sedangkan menurut Adam Smith, modal terbagi dalam dua aspek, yaitu $^{28}$ :

\footnotetext{
${ }^{23}$ Muhammad, Ekonomi Mikro dalam Perspektif Islam. 2004. Yogyakarta: BPFE Yogyakarta. hal 225 ${ }^{24}$ Ibid

${ }^{25}$ M.A. Mannan, Teori dan Praktek Ekonomi Islam, Yogyakarta: PT Dana Bhakti Prima Yasa, 1997, hal 59

${ }^{26}$ Muhammad, Ekonomi Mikro dalam Perspektif Islam. 2004. Yogyakarta: BPFE Yogyakarta. hal 226

${ }^{27}$ Afzalurrahman. Doktrin Ekonomi Islam Jilid 1. Terjemahan Soeroyo, Nastangin. Yogyakarta: PT Dana Bhakti Prima Yasa. 1995. hal 287

${ }^{28}$ Muhammad, Ibid 226
} 
a. Modal produksi, yaitu modal yang menghasilkan barang-barang sehingga dapat langsung dikonsumsi atau dipakai dalam produksi

b. Modal individu (modal leuntungan), yaitu modal yang memberikan hasil kepada pemiliknya setelah modal itu dipergunakan orang lain dengan menarik keuntungan

Menurut sistem ekonomi kapitalis, modal bisa dimiliki tiap individu maupun umum, sedang dalam sistem ekonomi sosialis adalah hak milik semua orang. Dalam Islam, modal (sebagai hak milik) adalah amanah dari Allah yang wajib dikelola secara baik. Manusia hanya diamanahi Allah untuk mengelola harta (modal) sehingga berkembang. Islam memiliki terapi terhadap perlakuan modal sebagai salah satu faktor produksi, yaitu ${ }^{29}$ :

a. Islam melarang penimbunan dan menyuruh membelanjakannya, dan menyuruh segera memutar harta yang belum produktif, jangan sampai termakan oleh zakat

b. Islam mengijinkan hak milik atas modal, dan mengajarkan untuk berusaha dengan cara-cara lain agar modal tidak berpusat hanya pada beberapa tangan saja

c. Islam mengharamkan peminjaman modal dengan cara menarik bunga

d. Islam mengharamkan penguasaan dan pemilikan modal selain dengan caracara yang diizinkan secara syariah, seperti: kerja, hasil akad jual-beli, hasil pemberian, wasiat, dan waris

e. Islam mewajibkan zakat atas harta simpanan atau harta produktif dalam bentuk dagang tiap tahunnya

f. Tidak boleh menggunakan modal dalam produksi secara boros

Sistem ekonomi Islam yang bebas bunga tidak memperkenankan memainkan pengaruhnya yang merugikan pekerja, produksi, dan distribusi. Sehingga dalam ekonomi Islam, modal memiliki tempat yang khusus. Dalam hal ini kita cenderung menganggap modal sebagai sarana produksi yang menghasilkan

${ }^{29}$ Muhammad, Ibid. hal 227 
tidak sebagai faktor produksi pokok, melainkan sebagai suatu perwujudan tanah dan tenaga kerja sesudahnya ${ }^{30}$.

Berdasarkan hal tersebut, Islam menyetujui dua pembentukan modal yang berlawanan yaitu konsumsi sekarang yang berkurang dan konsumsi mendatang yang bertambah. Dengan demikian memungkinkan modal memainkan peranan yang sesungguhnya dalamproses produksi ${ }^{31}$.

\section{Manajemen (Organisasi)}

Manajemen merupakan naungan segala unsur produksi dalam suatu usaha produksi, baik industri, pertanian, perdagangan, dengan tujuan agar mendapatkan laba secara terus-menerus dengan memfungsikan dan menyususn unsur-unsur tersebut serta menentukan ukuran seperlunya dari tiap unsur itu dalam perusahaan. Manajemen adalah upaya sejak mulai timbulnya ide usaha dan barang apa yang ingin diproduksi, berapa dan kualitasnya bagaimana dalam angan-angan si manajer ${ }^{32}$. Afzalurrahman menyatakan bahwa dalam industri modern, organisasi memainkan peranan yang sangat berarti dan dianggap sebagai faktor produksi yang paling penting ${ }^{33}$.

Islam menyuruh melakukan manajemen dan mengharuskan manajer mengikuti jalan keadilan dan menjauhi jalan yang membahayakan mayarakat. Maka dari itu dilarang memproduksi barang dan jasa yang haram. Namun Islam memperbolehkan mengambil keuntungan dengan menekannkan manajemen, perhitungan dan mencari keuntungan berdasarkan asas sama-sama mengalami untung dan rugi.

Menurut M.A. Mannan, ciri-ciri khusus organisasi Islam, yaitu ${ }^{34}$ :

a. Ekonomi Islam pada hakekatnya lebih berdasarkan ekuiti daripada pinjaman.

Para manajer cenderung mengelola perusahaan dengan pandangan untuk

\footnotetext{
${ }^{30}$ M.A. Mannan, Teori dan Praktek Ekonomi Islam, Yogyakarta: PT Dana Bhakti Prima Yasa, 1997, hal 59

31 Ibid. hal 62

${ }^{32}$ Muhammad, Ekonomi Mikro dalam Perspektif Islam. 2004. Yogyakarta: BPFE Yogyakarta. hal 228

${ }^{33}$ Afzalurrahman. Doktrin Ekonomi Islam Jilid 1. Terjemahan Soeroyo, Nastangin. Yogyakarta: PT Dana Bhakti Prima Yasa. 1995. hal 297

${ }^{34}$ M.A. Mannan, Teori dan Praktek Ekonomi Islam, Yogyakarta: PT Dana Bhakti Prima Yasa, 1997, hal 229
} 
membagi deviden kepada para pemegang saham atau berbagi keuntungan diantara mitra usaha

b. Pengertian keuntungan biasa mempunyai arti yang lebih luas dalam kerangka ekonomi Islam karena tidak dikenalkan bunga pada modal. Modal manusia yang diberikan manajer harus diintegrasikan dengan modal berbentuk uang. Sehingga terjadi perpaduan penanaman modal dan usahawan dimana keuntungan menjadi urusan bersama

c. Sifat terpadu organisasi ini menuntut integritas moral, ketepatan, dan kejujuran dalam akuntansi mungkin lebih dibutuhkan daripada organisasi secular manapun, yang para pemilik modalnya mungkin bukan merupakan bagian mdari manajemen. Islam menekankan kejujuran, ketepatan, kesungguhan dalam urusan perdagangan karena mengurangi biaya penyediaan (supervisi) dan pengawasan.

d. Faktor manusia dalam produksi dan strategi uasaha barangkali mempunyai signifikansi lebih diakui dibandingkan dengan strategi manajemen lainnya yang didasarkan pada memaksimalkan keuntungan atau penjualan.

\section{Fungsi Produksi}

Fungsi produksi menggambarkan jumlah input dan output (baik itu barang maupun jasa) yang dapat dihasilkan dalam satu waktu periode. Fungsi produksi untuk memproduksi barang Q untuk dua variabel independen dapat diformulasikan sebagai $\mathrm{Q}=\mathrm{f}(\mathrm{K}, \mathrm{L})$ yang menunjukkan berapa jumlah maksimal barang $\mathrm{Q}$ yang dapat diproduksi dengan menggunakan berbagai alternatif kombinasi input modal (K) dan tenaga kerja $(\mathrm{L})^{35}$.

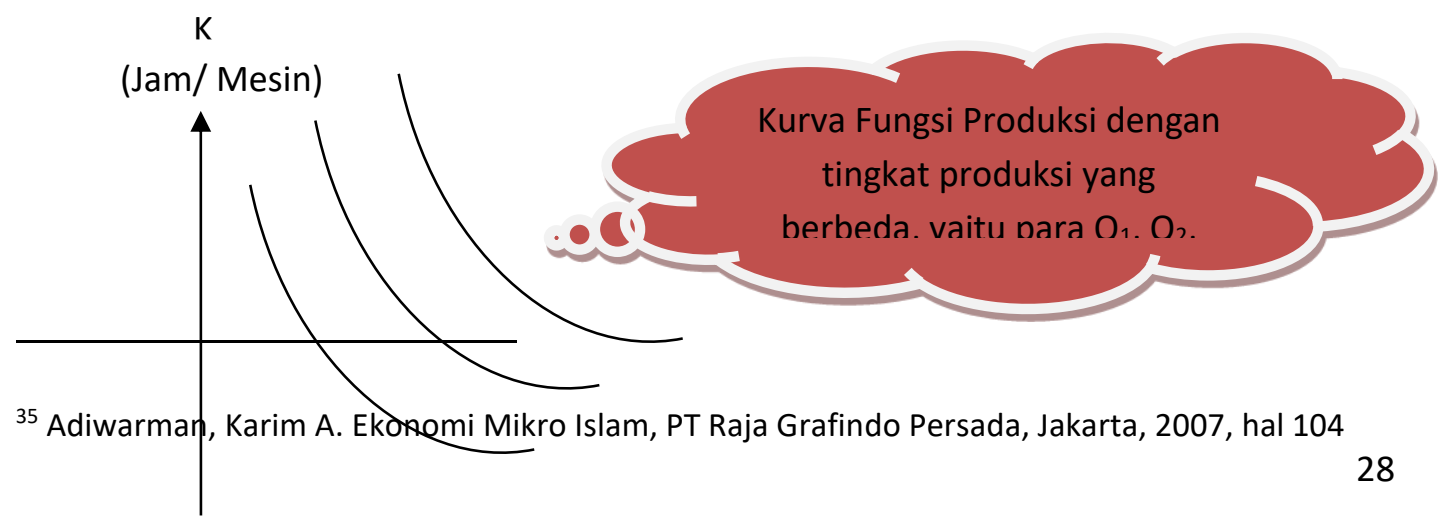




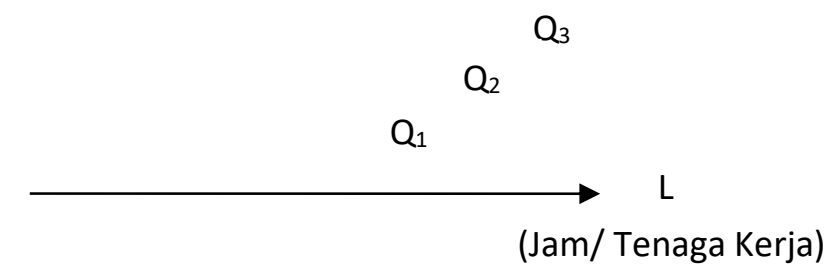

\section{Gambar 1. Fungsi Produksi dengan Dua Variabel Independen}

\section{Fungsi Produksi: Produksi Total, Produk Marginal, dan Produk Rata-rata}

Analisa mengenai produksi meliputi beberapa penilaian yang terdiri dari produksi total (total production), produksi marginal (marginal production), dan produksi rata-rata (average production). Berikut penjelasan rincinya ${ }^{36}$ :

a. Produksi Total (TP), adalah keseluruhan jumlah produksi yang dikeluarkan oleh seorang pengusaha. Produksi total diperoleh dari mengalikan jumlah barang yang diproduksi (Q) dengan harga barang (P). Total produksi dapat diformulasikan sebagai berikut:

$$
\mathbf{T P}=\mathbf{Q} \times \mathbf{P}
$$

b. Produksi marginal (MP) adalah tambahan yang diakibatkan oleh penambahan satu faktor produksi yang digunakan. Apabila $\Delta \mathrm{X}$ adalah tambahan faktor produksi, $\Delta \mathrm{TP}$ adalah pertambahan produksi total, maka produksi marginal dapat diformulasikan dalam bentuk sebagai berikut:

$$
M P=\Delta T P / \Delta X \text { atau } M P=d Q / d X
$$

c. Produksi rata-rata (AP) adalah produksi yang secara rata-rata yang dihasilkan factor produksi. Apabila produksi total adalah TP, jumlah produksi adalah X, maka produksi rata-rata dapat diformulasikan dalam bentuk sebagai berikut:

$$
\mathbf{A P}=\mathbf{T P} / \mathbf{X} \text { atau } \mathbf{A P}=\mathbf{Q} / \mathbf{X}
$$

Berikut adalah contoh aplikasinya dalam perhitungan:

Soal $^{37}$ :

\footnotetext{
${ }^{36}$ Heri Sudarsono, Konsep Ekonomi Islam Suatu Pengantar, Ekonisia, Yogyakarta, 2002, hal 194

${ }^{37}$ Adiwarman, Karim A. Ekonomi Mikro Islam, PT. Raja Grafindo Persada, Jakarta, 2007, hal 105
} 
Satu orang pekerja mampu menghasilkan 23 boneka setiap harinya, namun ketika ada tambahan tenaga dari orang kedua maka satu hari jumlah boneka yang diproduksi mencapai 60 boneka. Dengan demikian kemampuan tiap indivisu ketika dua orang secara bersama-sama berproduksi meningkat menjadi 30 buah boneka. Dengan demikian sampai dengan masuknya 10 orang tenaga kerja, maka fungsi dari total produksi dapat dituliskan sebagai berikut:

$$
Q=14 X+10 X^{2}-X^{3}
$$

Sedangkan MP adalah hasil derivasi pertama dari fungsi total produksi:

$$
\begin{gathered}
M P=d Q / d X \\
M P=14+20 X-3 X^{2}
\end{gathered}
$$

Dimana artinya: setiap penambahan satu unit input dapat berdampak kepada peningkatan keluaran, sehingga apabila setiap tambahan satu unit mempunyai dampak yang lebih kecil maka berlakulah hukum "the law of diminishing returns" Sedangkan rata-rata kemampuan produksi dari setiap individu atau input dapat dinotasikan sebagai average product yang diperoleh dari:

$$
\mathbf{A P}=\mathbf{Q} / \mathbf{X}
$$

\begin{tabular}{|c|c|c|c|c|}
\hline $\begin{array}{c}\text { Unit of } \\
\text { Variabel } \\
\text { Input }(X)\end{array}$ & $\begin{array}{c}\text { Quantity of } \\
\text { Output } \\
\text { Q=14X+10X } \\
X^{3}\end{array}$ & $\begin{array}{c}\text { Discreate } \\
\text { Marginal } \\
\text { Product of } \\
\text { Variabel } \\
\text { Input }\end{array}$ & $\begin{array}{c}\text { Continous } \\
\text { marginal } \\
\text { Product of } \\
\text { Variabel } \\
\text { Input } \\
\text { MP=14+20X- } \\
\mathbf{3 X}^{\mathbf{2}} \\
\mathrm{MP}=\mathrm{dQ} / \mathrm{dX} \\
\end{array}$ & $\begin{array}{c}\text { Average } \\
\text { Prodduct of } \\
\text { Variabel } \\
\text { Input } \\
\text { AP=14+10X- } \\
\mathbf{X}^{\mathbf{2}} \\
\mathbf{A P}=\mathbf{Q} / \mathbf{X}\end{array}$ \\
\hline 0 & 0 & & 14 & 14 \\
\hline 1 & 23 & 23 & 31 & 23 \\
\hline 2 & 60 & 37 & 42 & 30 \\
\hline
\end{tabular}

$$
A P=14+10 X-X^{2}
$$

Tabel 1. Aplikasi Perhitungan TP, MP dan AP ${ }^{38}$

\footnotetext{
38 ibid, hal 106
} 


\begin{tabular}{|c|c|c|c|c|}
\hline 3 & 105 & 45 & 47 & 35 \\
\hline 4 & 152 & 47 & 46 & 38 \\
\hline 5 & 195 & 43 & 39 & 39 \\
\hline 6 & 228 & 33 & 26 & 38 \\
\hline 7 & 245 & 17 & 7 & 35 \\
\hline 8 & 240 & -5 & -18 & 30 \\
\hline 9 & 207 & -33 & -49 & 23 \\
\hline 10 & 140 & -67 & -86 & 14 \\
\hline
\end{tabular}

\section{Kurva Jangka Pendek dari Fungsi Produksi; Hubungan antara Fungsi Produksi, Marginal Product dan Average Product ${ }^{39}$}

Point of diminishing marginal return (DMR), pada poin setiap ada penambahan input maka akan memberikan peningkatan yang lebih besar terhadap output yang tercipta. Pada kondisi demikian, jumlah output masih dapat terus ditingkatkan dengan menambah input. Titik A dapat ditarik dari titik tertinggi dari kurva marginal product. Pada poin A inilah keuntungan yang diperoleh oleh produsen mencapai tingkat yang tertinggi, namun secara kuantitas, jumlah output yang diproduksi belum mencapai tingkat yang maksimal. Artinya optimalisasi resources seperti yang dikehendaki oleh ekonomi Islam belum dapat tercapai apabila produsen berproduksi pada saat tingkat marginal product mencapai puncaknya.

Apabila kurva marginal produk berpotongan dengan average product maka dapat ditarik garis lurus dan didapatkan poin B. Pada saat tingkat produksi berada pada poin B, berapa hal yang berkaitan dengan fungsi produksi adalah sebagai berikut:

a. Tingkat marginal product mengalami penurunan walaupun belum mencapai tingkat 0 , hal ini mengindikasikan bahwa penambahan input pada poin B masih memberikan penambahan output secara positif, namun tingkat penambahan sebagai akibat dari penambahan 1 unit input menjadi berkurang

b. Poin B berada pada saat average product berada pada level tertinggi, atau titik balik. Artinya penambahan satu unit input pada level ini akan mengakibatkan

\footnotetext{
39 Ibid. hal 105-107
} 
terjadinya penurunan tingkat average product. Untuk selanjutnya poin B ini disebut dengan point of diminishing average return (DAR)

Point of diminishing return (DTR) tercapai ketika kurva production product mencapai titik maksimal. Pada titik $\mathrm{C}$ ini, kurva marginal product menyentuh pada titik 0 (nol). Artinya ketika poin $\mathrm{C}$ sudah dicapai, maka setiap penambahan unit input produksi akan berakibat pada menurunnya total output (atau mengalami kerugian). Dengan demikian, titik optimum produksi yang dilakukan oleh suatu industri adalah berada pada titik $\mathrm{C}$ ini. Pada titik $\mathrm{C}$ inilah, penggunaan sumber daya sudah mencapai titik optimal.

\section{Quantity of Output per}

Period of Time

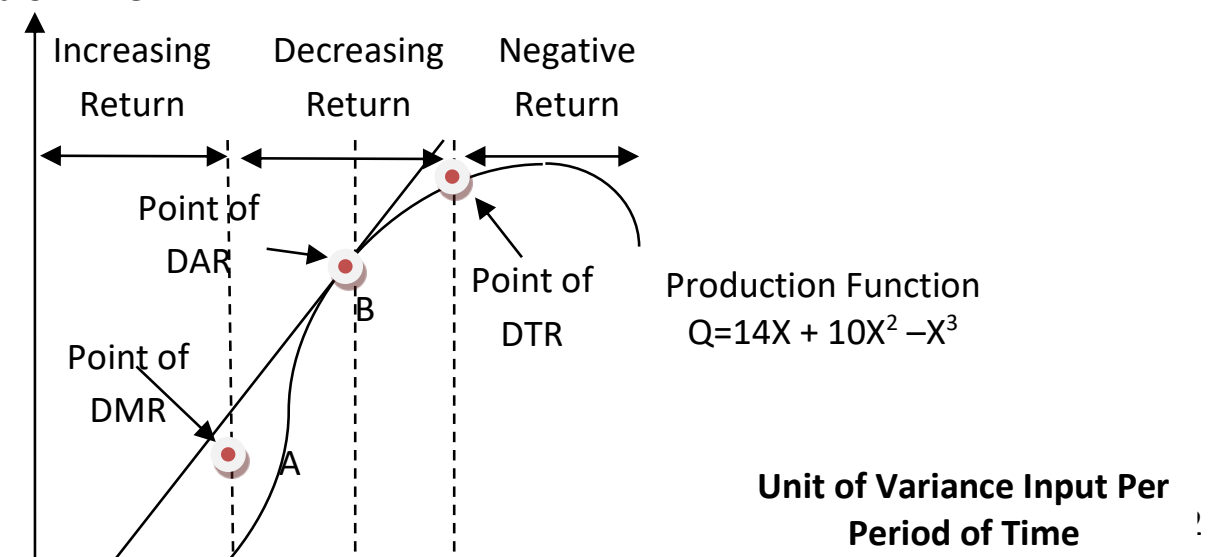




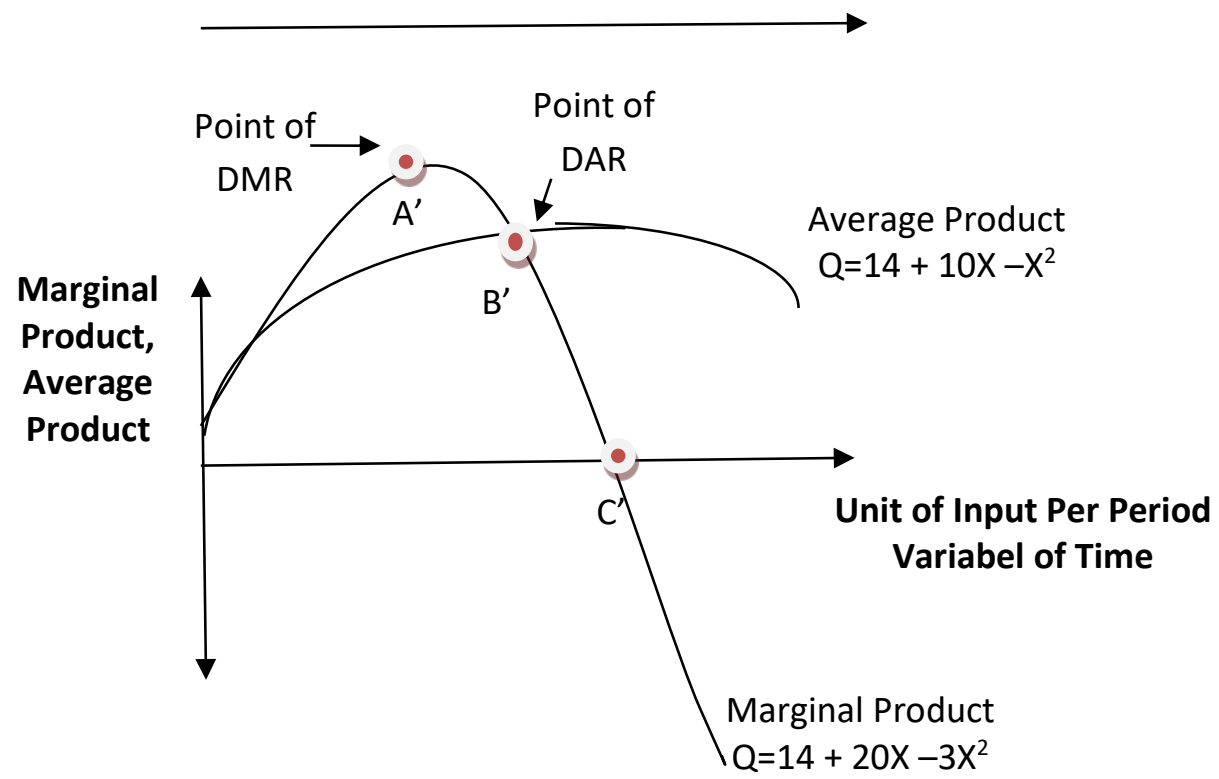

\section{Gambar 2 Kurva Jangka Pendek dari Fungsi Produksi: Hubungan antara Fungsi Produksi, Marginal Product dan Average Product}

\section{Alternatif Tipe Fungsi Produksi ${ }^{40}$}

Seperti gambar kurva jangka pendek dari fungsi produksi, kita bisa membagi menjadi 3 kemungkinan fungsi produksi yang terjadi yaitu: increasing return, decreasing return, ataupun negative return. Secara keseluruhan karakteristik fungsi produksi dapat diklasifikasikan sebagai berikut:

\section{a) Constant Return to Variable Input ${ }^{41}$}

Untuk produsen yang mempunyai fungsi linier, maka setiap kali penambahan variable input akan berdampak pada penambahan output yang besarnya sama antara input dan outputnya. Secara umum formula untuk menerangkan hubungan input dan output yang mempunyai fungsi linier dapat dirumuskan sebagai berikut:

$$
\mathbf{Q}=\mathbf{a}+\mathbf{b X}
$$

\footnotetext{
${ }^{40}$ Adiwarman, Karim A. Ekonomi Mikro Islam, PT. Raja Grafindo Persada, Jakarta, 2007, hal 108111

${ }^{41}$ Adiwarman, Karim A. Ekonomi Mikro Islam, PT. Raja Grafindo Persada, Jakarta, 2007, hal 108
} 
Dimana $\mathbf{Q}$ menunjukkan jumlah output, sedangkan $\mathbf{X}$ merepresentasikan jumlah unit input yang digunakan dalam periode waktu tertentu dan a dan b adalah konstanta. Seperti yang digambarkan pada grafik dibawah ini, fungsi produksi dimulai dari titik origin sehingga dapat dikatakan bahwa nilai konstanta a adalah nol, sehingga fungsi produksi dapat dituliskan menjadi:

$$
\mathbf{Q}=\mathbf{b} \mathbf{X}
$$

Dari formula tersebut kita dapat menurunkan fungsi tersebut untuk mendapatkan average dan marginal product seperti Gambar 3 di bawah:

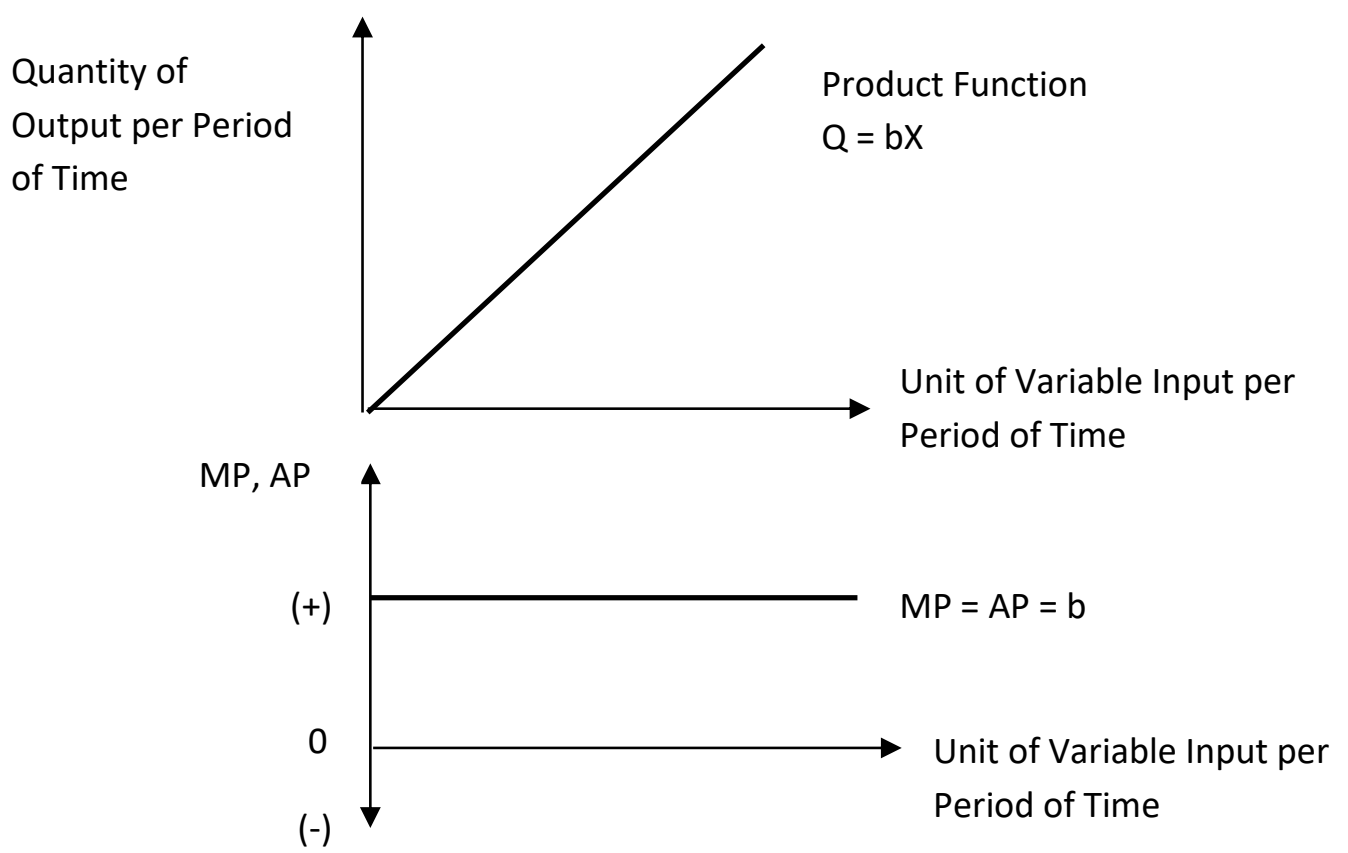

Gambar 3. Fungsi Produksi, MP dan AP Constant Return to Variable Input

Average product untuk constant return to variable input:

$$
\mathbf{A P}=\mathbf{Q} / \mathbf{X}=\mathbf{b X} / \mathbf{X}=\mathbf{b}
$$

Sedangkan marginal product (MP) adalah derivasi pertama dari fungsi produksi

$$
M P=d Q / d X=b
$$

Sehingga kita bisa menarik kesimpulan bahwa $\mathbf{A P}=\mathbf{M P}=\mathbf{b}$, sehingga kalau kita melihat dalam gambar di atas, AP dan MP membentuk satu garis lurus yang konstan (b). Apabila sebuah produsen menghadapi fungsi constant return to variable input, maka setiap kali ada penambahan satu variable input akan meningkatkan jumlah output sebesar b. 


\section{b) Decreasing return to Variabel Input ${ }^{42}$}

Untuk produsen yang mempunyai fungsi simple quadrant, maka setiap kali dilakukan penambahan variable input akan berdampak pada penurunan jumlah output yang dapat diproduksi. Secara umum formula untuk menerangkan hubungan input dan output yang mempunyai fungsi simple quadrat dapat dirumuskan sebagai berikut:

$$
\mathbf{Q}=\mathbf{a}+\mathbf{b X}-\mathbf{c} \mathbf{X}^{2}
$$

Bila kita mengasumsikan fungsi dimulai dari titik originmaka formula di atas dapat ditulis sebagai berikut:

$$
\mathbf{Q}=\mathbf{b X}-\mathbf{c X}^{2}
$$

Dimana b adalah konstanta dan $\mathbf{c}$ mengindikasikan nilai yang negatif, karena nilai $\mathbf{b X}<\mathbf{c X}^{\mathbf{2}}$, maka setiap kali ada penambahan input $(\mathrm{X})$ maka akan berdampak pada penurunan nilai Q. Hubungan antara fungsi produksi tersebut dengan average dan marginal product dapat dituliskan sebagai berikut :

$$
\begin{gathered}
A P=Q / X=\left(b X-c X^{2}\right) / X=b-c X \\
M P=d Q / d X=b-2 c X
\end{gathered}
$$

Ketiga formula diatas dapat dillihat pada Gambar 4 berikut:

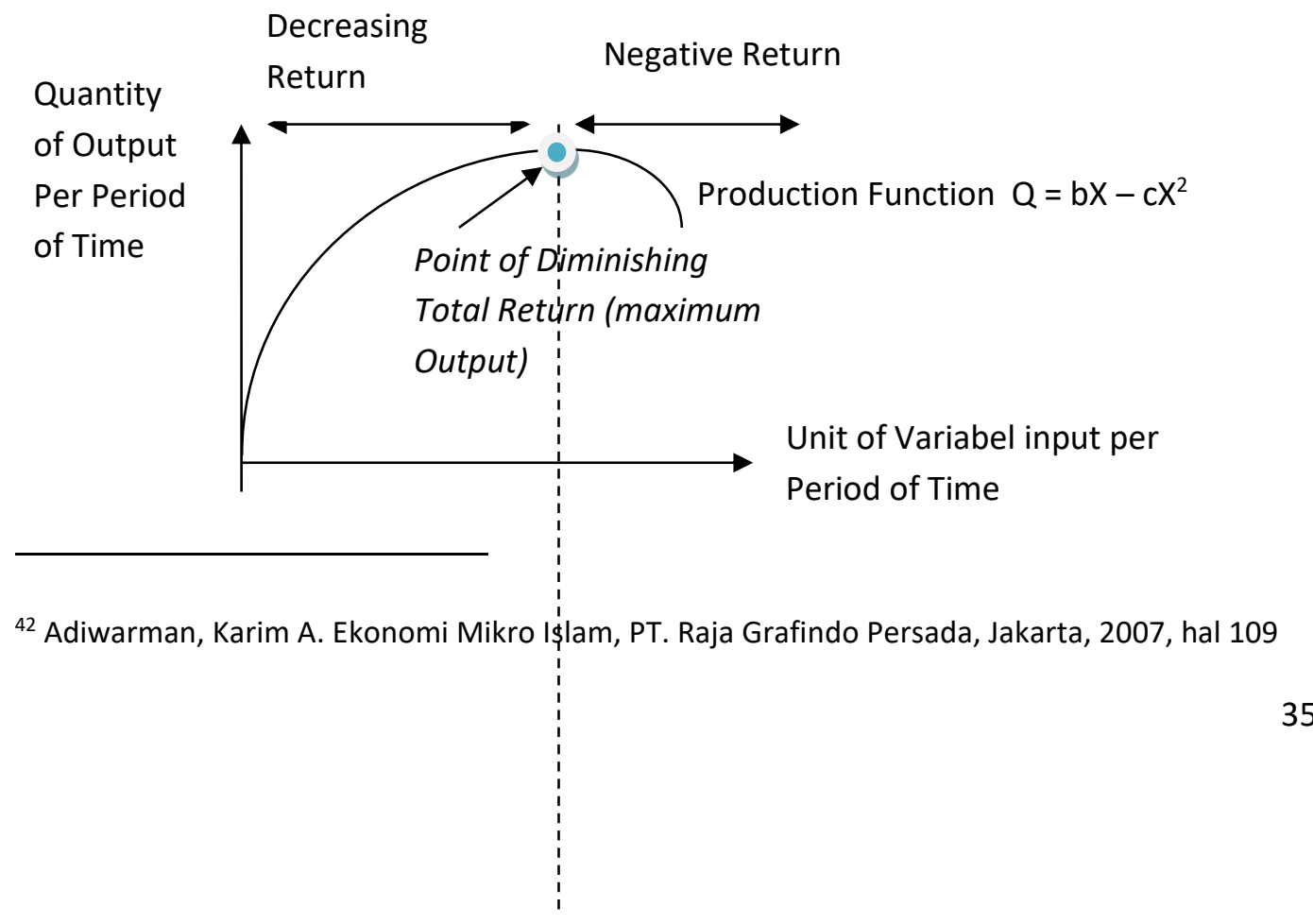




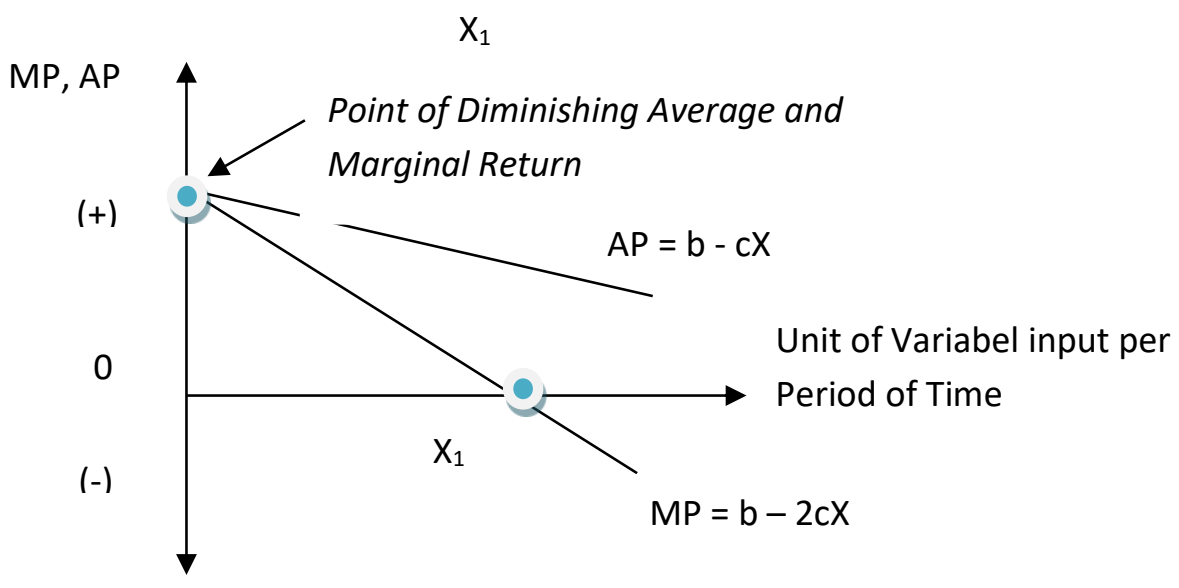

Gambar 4. Fungsi Produksi, MP dan AP Decreasing Return to Variabel Input

\section{c) Increasing Return to Variable Input ${ }^{43}$}

Karakteristik fungsi produksi yang terakhir adalah increasing return to variable input. Pada karakteristik yang terakhir inilah setiap penambahan input produksi maka akan berdampak pada peningkatan nilai tambah output yang diproduksi. Misalnya penambahan satu unit input yang pertama memiliki nilai tambah output sebesar 10 unit, sedangkan penambahan satu unit input yang kedua memiliki nilai tambah output sebesar 12 unit. Formula yang dapat digunakan untuk menerangkan kondisi ini adalah sebagai berikut:

$$
\mathbf{Q}=\mathbf{a}+\mathbf{b X}+\mathbf{c} \mathbf{X}^{2}
$$

Jika kita mulai dari titik origin, dan b dan c adalah positif, maka formula dari fungsi produksi adalah:

$$
\mathbf{Q}=\mathbf{b X}+\mathbf{c} \mathbf{X}^{2}
$$

Hubungan antara average dan marginal product dapat diformulasikan sebagai berikut:

$$
\mathbf{A P}=\mathbf{Q} / \mathbf{X}=\left(\mathbf{b X}-\mathbf{c X}^{2}\right) / \mathbf{X}=\mathbf{b}+\mathbf{c X}
$$

dan

$$
M P=d Q / d X=b+2 c X
$$

${ }^{43}$ Adiwarman, Karim A. Ekonomi Mikro Islam, PT. Raja Grafindo Persada, Jakarta, 2007, hal 110111 
Jika ketiga formula tersebut di atas dituangkan ke dalam bentuk kurva maka akan berbentuk seperti Gambar 5 di bawah. Pada gambar terlihat bahwa kurva MP berada di atas kurva AP. Hal ini terjadi karena slope keduanya yang berbeda, slope untuk kurva AP adalah (+c) sedang slope untuk kurva MP adalah $(+2 \mathrm{c})$. Dengan demikian, apabila kita masukkan variable input (X), maka setiap ada penambahan input, marginal product lebih besar bila dibandingkan dengan average product. Sampai batas berapa pun dampak dari penambahan input tidak akan menurunkan marginal product maupun total product

Quantity of Output per

Period of Time

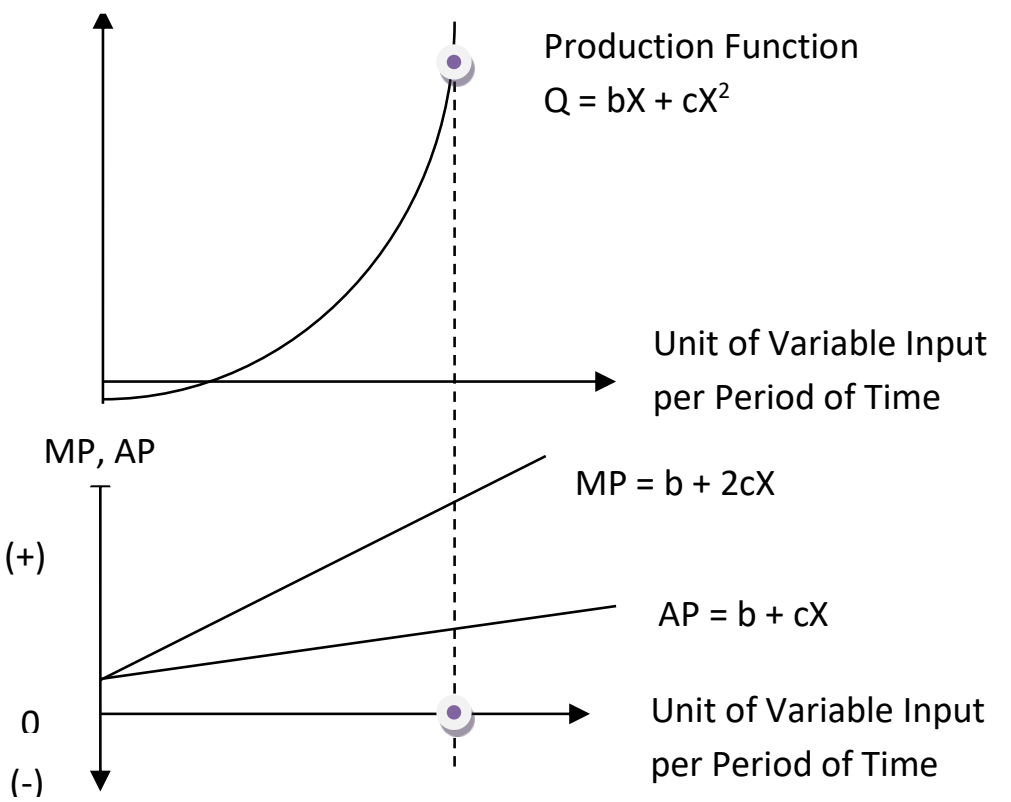

Gambar 5. Fungsi Produksi, MP, dan MP Increasing Return to Variable Input

\section{E. Kesimpulan}

Produksi dalam konvensional sebagai sebuah proses penambahan nilai guna atau manfaat suatu barang dengan tujuan kesejahteraan. Walaupun memiliki esensi yang sama dengan konvensional, tetapi ekonomi Islam memiliki perbedaan dalam mencapai kesejahteraan itu, karena dalam Islam ada tujuan lain tidak hanya kesejahteraan individu namun juga maslahah bagi masyarakat dan tidak hanya memikirkan keuntungan. Sehingga dalam Islam juga terdapat prinsip-prinsip dan kaidah-kaidah dalam berproduksi yaitu harus sesuai dengan syariat Islam. Dalam penggunaan factor-faktor produksi (tanah/alam, tenaga kerja, modal, dan 
organisasi) juga dilakukan sesuai ketentuan syariat Islam dan tidak merusak lingkungan. Optimalisasi resources seperti yang dikehendaki oleh ekonomi Islam belum dapat tercapai apabila produsen berproduksi pada saat tingkat marginal product mencapai puncaknya. Namun titik optimum produksi yang dilakukan oleh suatu industri adalah pada saat penggunaan sumber daya sudah mencapai titik optimal.

\section{Daftar Pustaka}

Afzalurrahman. 1995. Doktrin Ekonomi Islam Jilid 1. Terjemahan Soeroyo, Nastangin. Yogyakarta: PT Dana Bhakti Prima Yasa.

Sudarsono, Heri. 2002. Konsep Ekonomi Islam Suatu Pengantar. Yogyakarta: Ekonisia.

Mannan, M.A. 1997. Teori dan Praktek Ekonomi Islam. Yogyakarta: PT Dana Bhakti Prima Yasa.

Muhammad. 2004. Ekonomi Mikro dalam Perspektif Islam. Yogyakarta: BPFE Yogyakarta.

Karim, Adiwarman A. 2007. Ekonomi Mikro Islam. Jakarta: PT Raja Grafindo Persada.

Nasution, Mustafa Edwin. 2006. Pengenalan Eksklusif Ekonomi Islam. Jakarta: Kencana Prenada Media Grup.

Pusat Pengkajian dan Pengembangan Ekonomi Islam (P3EI) Universitas Islam Indonesia Yogyakarta atas kerjasama dengan Bank Indonesia. 2008. Ekonomi Islam. Jakarta: PT Raja Grafindo Persada. 